\title{
Effects on macroinvertebrate communities a year after the rehabilitation of an urban river (Tinto River, Portugal)
}

\author{
Jesus T. ${ }^{1, *}$ (iD and Monteiro A.2,3 \\ ${ }^{1}$ Rua de Castelo Branco, 204, $3^{\circ}$ Rec. Esq. Fr., 4400-450 Vila Nova de Gaia, Portugal. \\ 2 UFP Energy, Environment and Health Research Unit (FP-ENAS), Universidade Fernando Pessoa, Portugal. \\ Praça 9 de Abril, 349, Porto, Portugal. \\ ${ }^{3}$ LSRE-LCM, Faculdade de Engenharia da Universidade do Porto, Portugal. \\ * Corresponding author: tjesus123@gmail.com
}

Received: 02/02/21 Accepted: 29/11/21

\begin{abstract}
Effects on macroinvertebrate communities a year after the rehabilitation of an urban river (Tinto River, Portugal)

The Tinto River is a small urban watercourse in the Douro River basin (Portugal) that has been subject to various types of environmental disturbances over the years, which has led to severe degradation of its ecological status. Between 2013 and 2017, several studies were carried out to characterize and monitor some environmental parameters and to identify sources of environmental disturbances. From these studies, a set of actions and projects were undertaken in 2017-2019 to mitigate some of the environmental problems and to rehabilitate the river and its riverside areas. Here, we compare some parameters related to the river's ecological state (naturalness of the channel and banks, physicochemical conditions and benthic macroinvertebrate community) before the interventions and one year after the interventions at Tinto River. Conductivity, oxygen concentration and biotic indices improved after one year, especially during the adverse hydrological conditions brought on by a very dry summer and autumn with some flood episodes.
\end{abstract}

Key words: urban streams, river rehabilitation, ecological status, benthic macroinvertebrates

\section{RESUMO}

Um ano sobre a reabilitação de um rio urbano (rio Tinto, Portugal): efeito sobre as comunidades de macroinvertebrados bentònicos

O rio Tinto é um pequeno curso de água urbano da bacia do rio Douro (Portugal) que, ao longo dos anos, foi sujeito a vários tipos de perturbações ambientais, que conduziram a uma grande degradação do seu estado ecológico. Entre 2013 e 2017, vários estudos foram realizados com o objetivo de caracterizar e monitorar alguns dos parâmetros relacionados ao seu estado ecológico e detectar as principais fontes de perturbação ambiental. Os resultados obtidos nestes estudos levaram à realização entre 2017 e 2019 de um conjunto de ações e projetos para eliminar as principais fontes de perturbação ambiental e promover a reabilitação do rio e das suas zonas ribeirinhas. No presente estudo, comparamos os resultados de alguns parâmetros relacionados com o estado ecológico (naturalidade do canal e margens, alguns parâmetros físico-químicos e comunidade de macroinvertebrados bentónicos) do rio Tinto determinados antes das intervenções e após um ano das mesmas em alguns dos sectores do rio que foram alvo das intervenções. É possivel verificar alguma melhoria em pelo menos alguns dos parâmetros avaliados (condutividade, saturação de oxigénio e indices bióticos), mesmo considerando o curto tempo decorrido entre as intervenções e as condições hidrológicas adversas do ano corrente (um verão muito seco e um outono com alguns episódios de cheias).

Palavras chave: rios urbanos, reabilitação de ecossistemas lóticos, estado ecológico, macroinvertebrados bentónicos 


\section{INTRODUCTION}

The Tinto River (Fig. 1) has historically been a development enabler but not without environmental costs to the majority of its urban watercourses (Sheehan, 2001, Parrinello, 2014). The increase in intensive human activities, characterized by strong pressures to occupy banks, pollution, channelization, damming, agriculture, discharge of treated and untreated effluents and other factors, have led to changes in the hydrological and aquatic physical habitat conditions (Vieira, 2009, Jesus et al., 2020). These pressures contribute to significant river degradation reflected in the reduced water quality and increased abiotic conditions, with loss of biodiversity (Quinn \& Hickey, 1990, Grim et al., 2000, Zhang et al., 2014).

The European Water Framework Directive (2000/60/EEC of 22 December 2000, WFD) in Portugal (transposed into Portuguese law by Law No $58 / 2005$ on 29 December, as amended by Decree-Law no. 245/2009 on September 22, and by Decree-Law no. 77/2006 on March 30, amended by Decree-Law no. 103/2010 on September 24 ) is a legal instrument for improving the ecological quality of surface waters in all EU member states and for reaching good ecological status.

The "ecological status" is based on several parameters (hydromorphological, physical, chemical and biological) and tools (indices, metrics, techniques) to determine the overall health of an ecosystem.

Within the European Water Framework Directive, benthic invertebrates are widely used in ecological quality assessments of surface waters since they are reliable indicators of temporal and spatial changes in aquatic habitats (Yoder \& Rankin, 1995, Concepción et al., 2015) and water quality (Resh and Rosenberg, 1993, Carter et al., 2017). For this reason, they are commonly used to monitor and assess river rehabilitation efficiency (Peterson, 2015, Rubin et al., 2017).

To fulfil the EU's directives, some severely impacted areas must be rehabilitated (e.g., Ormerod, 2004, Al-Zankana et al., 2020), so the four municipalities of the Tinto River catchment, municipal companies and nongovernmental organizations promoted two monitoring programs (between 2013 and 2015 and between 2015 and 2017) to evaluate the ecological status of the river and to identify its main sources of disturbance. These activities revealed a very adverse ecological status for the Tinto River (Fig. 2) with the following main sources of ecosystem environmental problems: (1) a malfunction of a domestic wastewater pumping station in Granja Creek, (2) urbanization and bank degradation in the middle sector at the 4th kilometre, periodically polluted by Castanheira, and (3) discharges from two wastewater treatment plants in the last sector of the river.

Two rehabilitation plans were set up (between September 2017 and May 2019) (Fig. 2) aiming to

- improve the water quality of the Granja and Castanheira Creeks for bank stabilization of the Tinto River, construction of a green urban park around the mouth of the Castanheira Creek, elimination of some occasional discharges on the Tinto River, construction of an outfall to divert effluents from the WWTPs and stabilise the river banks via construction of a pedestrian path along the river and enlargement of the Porto oriental urban park.

Understanding the effectiveness of river rehabilitation techniques is essential for guiding the planning and design of future rehabilitation projects (Roni \& Quimby, 2005). The need for effective monitoring to achieve this was recognized (Roni \& Beechie, 2013). These actions are still rare (Palmer et al., 2010, Kail et al., 2012), although the strong and long-term positive ecological effects of hydromorphological rehabilitation are evident, particularly for macroinvertebrates (Palmer et al., 2010, Kail et al., 2012).

It is necessary to monitor rehabilitation measures to evaluate their effectiveness so that the process is continuous and can be extended to include different aspects of the river. In this case, the study of benthic macroinvertebrate communities is particularly important, as they are the main biotic community present in the river (Jesus et al., 2020) and their characteristics and importance allow for the assessment of the quality of aquatic ecosystems. Therefore, the main objective of this study is to evaluate the effectiveness of the Tinto River rehabilitation activities in terms of water chemical quality and benthic macroinvertebrate community composition. 


\section{METHODOLOGY}

\section{Study area}

The Tinto River is a small northern Portuguese river (INAG, 2008b) approximately $11.4 \mathrm{~km}$ long. The river's spring is located at $200 \mathrm{~m}$ a.s.l. in Valongo and flows into the right bank of the Douro River estuary (Porto) passing through the municipalities of Maia and Gondomar (Fig. 1) (Pinho et al., 2009) with a watershed area of $23.5 \mathrm{~km}^{2}$. The river is highly degraded mainly by bank utilization and discharges from two WWTPs (Meiral at Rio Tinto and Freixo at Porto), resulting in a significant increase in water pollution (Vieira, 2009, Jesus et al., 2020) in terms of nutrients, BOD (Biochemical Oxygen Demand) and organic matter (Jesus et al., 2020), and a high degree of degradation of its hydromorphological conditions (artificial margins, channelling, culverts, absence of riparian vegetation).

\section{Sampling}

To verify the effectiveness of the river rehabilitation measures, our study compared the values of some ecological quality parameters collected after the implementation of the measures and the average of the values obtained during the last two-years of the monitoring period (2015-2017). Sampling was performed during the same periods under similar climatic and hydrological conditions at five sampling sites along the river in the areas where the rehabilitation river works were implemented (Figs. 1 and 2):

Site A, downstream of the first intervention area and approximately $4 \mathrm{~km}$ from the source of the river; Site B, approximately $7 \mathrm{~km}$ from the source of the river, downstream of the area of the Tinto River urban park and at the beginning of the pedestrian path, along the last $7.5 \mathrm{~km}$ of the Tinto River; Sites C, D and E, approximately 8, 10 and $11 \mathrm{~km}$ from the river source, in an area where the construction of an emissary for diverting the discharges of the two WWTPs occurred, along with the rehabilitation of the river banks and the construction of a pedestrian path along the river banks.

The benthic macroinvertebrate samples were collected with a hand net with a $0.250 \mathrm{~mm}$ mesh by mesohabitat, following the official Portuguese sampling protocols (INAG, 2008a), and fixed in $4 \%$ buffered formaldehyde. The invertebrate or-

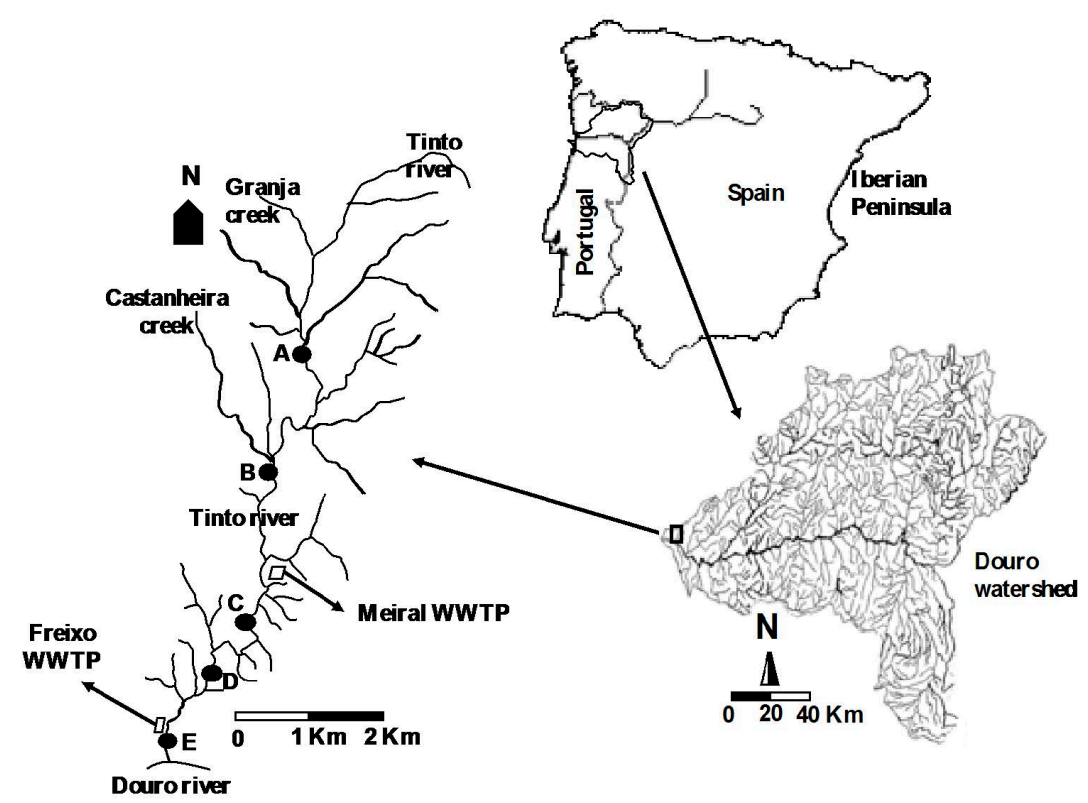

Figure 1. Sampling sites at Tinto River (Portugal). Pontos de amostragem no rio Tinto. 


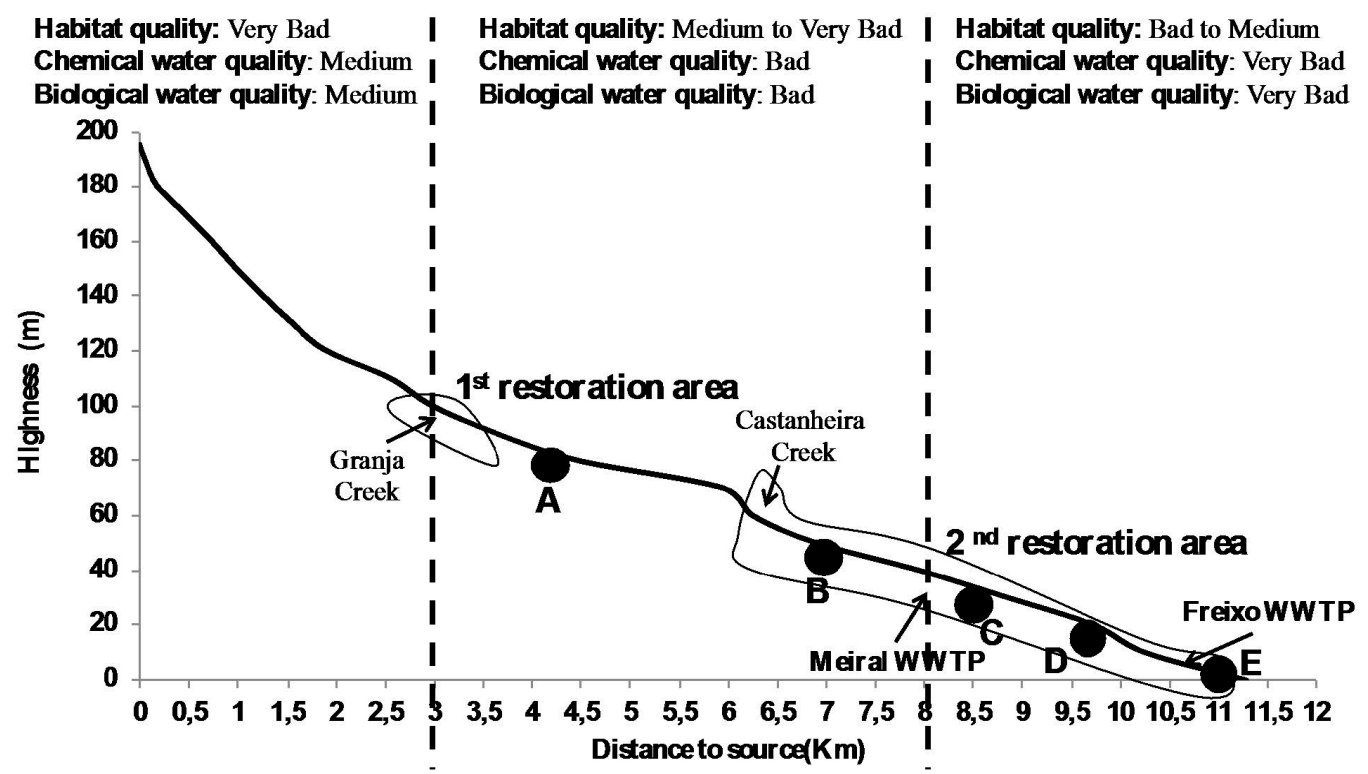

Figure 2. Tinto River profile with sampling sites, quality sectors (2015/17 monitoring results) and restoration areas (Portugal). Perfil do rio Tinto com localização dos pontos de amostragem, calssificação da qualidade (monitorização e 2015/17) e localização as áreas de reabilitação.

Table 1. Abiotic parameters analyzed on the sampling points of the Tinto River, their methods, units and bibliography references. Parâmetros abióticos analisados nos pontos de amostragem do rio Tinto, metodologias, unidades e referências bibliográficas.

\begin{tabular}{llcc}
\hline Parameter & Method & Units & Bibliographic reference \\
\hline Width and Depth & In loco, with a meter & $\mathrm{m}$ & (Jesus, 2002) \\
\hline Water velocity & In loco with a flow meter & $\mathrm{m} / \mathrm{s}$ & (Platts et al., 1983) \\
\hline Flow & In lab, calculated through the with, depth and water velocity data & $\mathrm{m}^{3} / \mathrm{s}$ & (Jesus, 2002) \\
\hline Canopy & In loco, by visual observation of area of the river with shadow & & \\
\hline Macrophytes & In loco, by visual observation of covered area of the river bed & $\%$ & \\
\hline Substrate & In loco, by visual observation of the proportion of each substrate & & \\
\hline Conductivity & In loco, with an electrometric, using a portable apparatus & uS/cm & \\
\hline pH & In loco, with an electrometric, using a portable apparatus & $\begin{array}{c}\text { Sorensen } \\
\text { scale }\end{array}$ & \\
\hline Oxygen saturation & E In loco, with an electrometric, using a portable apparatus & $\%$ O2 & \\
\hline
\end{tabular}

ganisms were preserved in $70 \%$ alcohol after being sorted and identified to the family level, except for Oligochaeta (INAG, 2009). When the number of organisms was greater than 300 per sample, subsampling was performed (INAG, 2008a).

Physical and chemical water characteristics (conductivity, $\mathrm{pH}$ and oxygen saturation), flow, depth and width, macrophyte cover, canopy cover and sediment grain size were additional characteristics measured at the sites (see details in Table 1).

\section{Data analysis}

Two indices were calculated based on the hydromorphological parameters of the Tinto River: QBR (“Calidad del Bosque de Ribera” of Munné 
Table 2. Biological water Quality and metrics calculated with the benthic macroinvertebrate data, and bibliography references. Indices de qualidade biológica da água e métricas calculados com base nos dados de macroinvertebrados e referências bibliográficas.

\begin{tabular}{llr}
\hline Index/metrics & Definition & Bibliographic reference \\
\hline IBMWP & Iberian Bio-Monitoring Working Party Index & (Alba Tercedor et al., 2002) \\
\hline RQE & Ecological quality ratio & (INAG, 2009) \\
\hline Abundance & Total number of organisms & (INAG, 2009) \\
\hline Richness & Total number of taxa & (INAG, 2009) \\
\hline Diversity & Shannon diversity Index & (INAG, 2009) \\
\hline Equitability & Pielou equitability Index & (INAG, 2009) \\
\hline EPT families & Total number of Ephemeroptera, Plecoptera and Trichoptera families & (INAG, 2009) \\
\hline Diptera families & Total number of Diptera families & (INAG, 2009) \\
\hline$\%$ Trichoptera & Percent of Trichoptera larvae & (EPA, 1999) \\
\hline$\%$ CHIRONOMIDAE & Percent of CHIRONOMIDAE larvae & (EPA, 1999) \\
\hline$\%$ clingers & Percent of insect larvae having fixed retreats or adaptations for attachment to & (EPA, 1999) \\
\hline$\%$ rheophiles & surfaces in flowing water & (EPA, 1999) \\
\hline$\%$ branchial and cutaneous & Percent of insect larvae having preferences for water with velocity under 0,3 m/s & (EPA, 1999) \\
\hline
\end{tabular}

et al., 1998), successfully used in the Iberian Peninsula for assessment of the conservation state of river banks, and a visual evaluation index of habitat (AVH) for high-gradient rivers (EPA, 1999), applied in many countries to assess the state of riverbeds considering their structure and capacity to accommodate aquatic life (Barbour, 1997). The values were compared with the water quality classes proposed by Casatti et al. (2006).

We applied two water biological quality indices, IBMWP (Alba-Tercedor et al., 2002) and RQE ("Ratio Qualidade Ecológica"), derived from the proposed multimetric index for the rivers of North Portugal - IPtIN (INAG, 2009).

The macroinvertebrate community was evaluated based on its taxonomic composition and aspects related to the ecology and biological traits of the organisms. The organisms were grouped by respiratory physiology, feeding type, preference for habitat and mobility, and preferences for the current speed regime (Table S1, Supplementary information, available at http://www.limnetica.net/ en/limnetica) (Jesus, 2002; Jesus, 2008). The use of multivariate analysis of taxonomic and trait compositions (Table 2) allows different types of community responses to be examined.

The environmental parameters (hydromorphological and physicochemical) and macroinvertebrate metrics were subjected to principal component analysis (PCA) after data standardization.
To assess rehabilitation effects on the functional parameters and structures of benthic macroinvertebrate communities, a nonmultidimensional scaling analysis (n-MDS) was performed. The n-MDS was based on a similarity matrix calculated by the Euclidean distance between the percentage distribution of the organisms of each macroinvertebrate sample in their taxa in each ecological trait considered.

To validate the differences between the two clusters of samples (2015/17 and 2020), an ANOSIM analysis was performed. A SIMPER analysis was also carried out to assess the similarities within each theoretical cluster of samples (clusters: $2015 / 17$ and 2020) as well as the dissimilarities between the two clusters to determine the groups of organisms that are responsible for discriminating the difference between the two clusters. PCA was performed using STATISTICA 6.0, and the n-MDS, ANOSIM and SIMPER analyses were applied using PRIMER 5.2.2.

\section{RESULTS}

\section{Environmental parameters}

The analysis of the composition of the substrate (Fig. 3) shows that there was a predominance of the coarsest grain size sediments in the riverbed and that there were no great differences between 


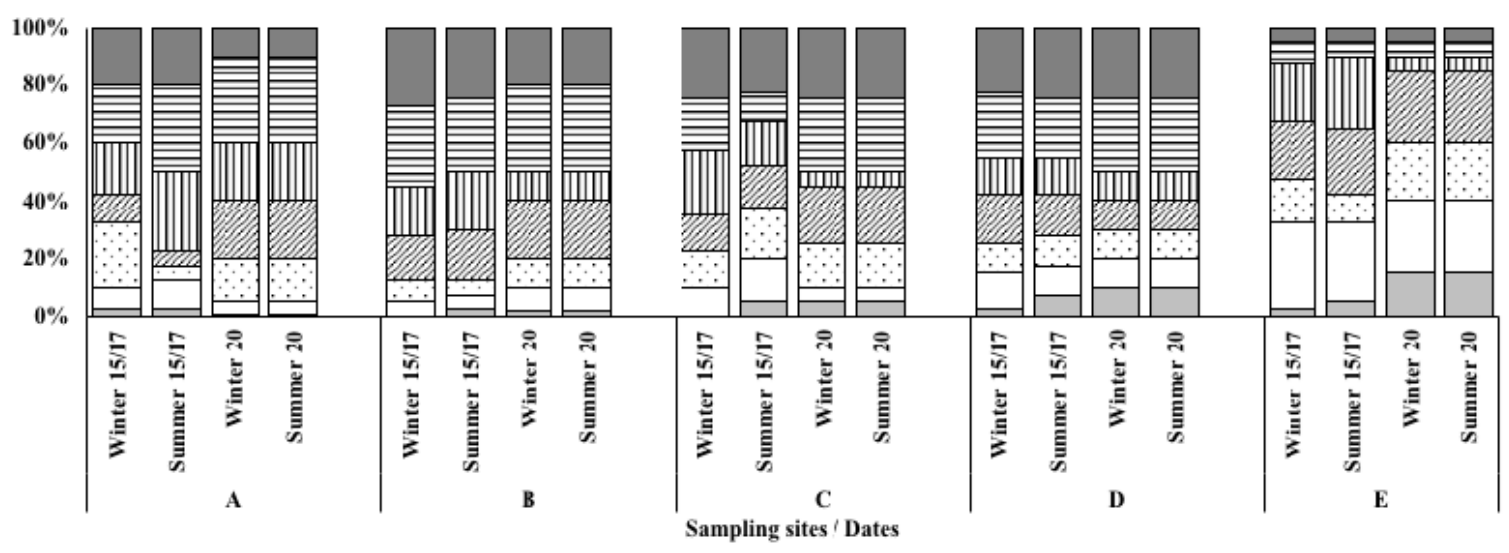

口mud $\square$ silt $\square$ gravel $\square$ pebble $\square$ cobble $\boxminus$ small blocks $\square$ blocks

Figure 3. Substrate composition in each sampling site. Composição do substrato em cada ponto de amostragem.
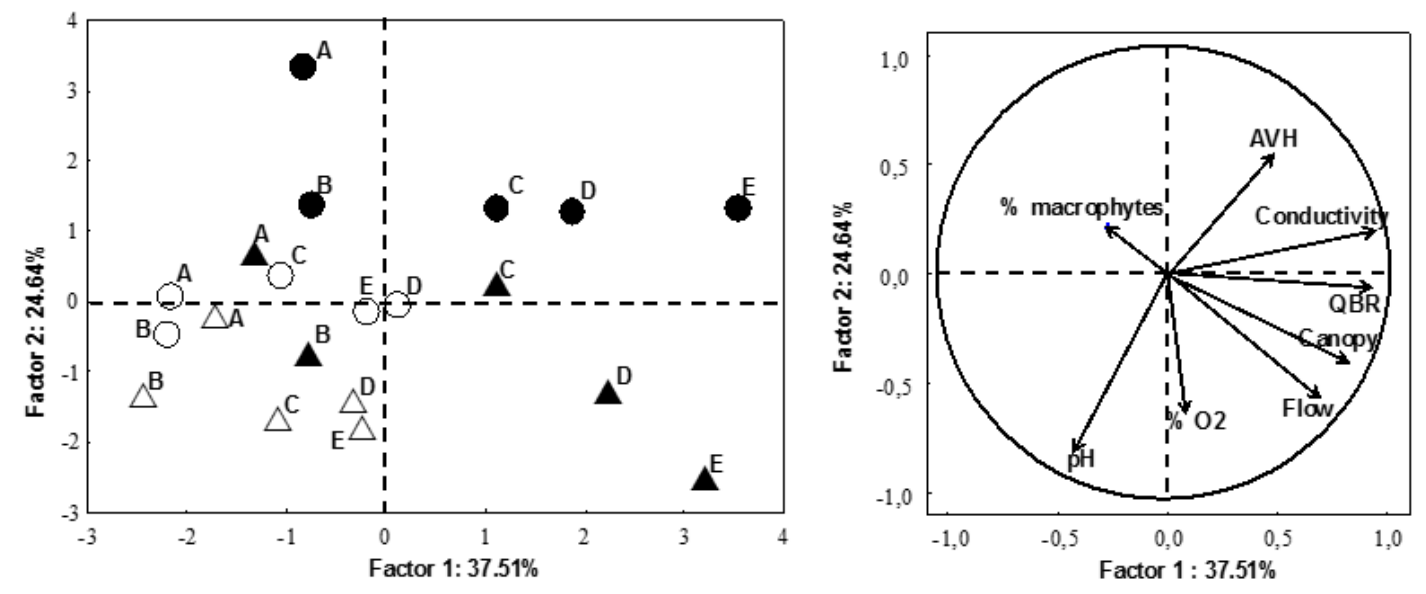

$\boldsymbol{\Delta}$ - Winter 2015/17 $\triangle$ - Winter 2020 - Summer 2015/17 ○ - Summer 2020

Figure 4. Principal components analysis (PCA) based on the mean values of the environmental parameters: left) sample ordination of all sampling sites in the space formed by the two first factors; right) correlation circle of the hydromorphological parameters with the two first factors. Análise em componentes principais (PCA) baseada nos valores médios dos parâmetros ambientais: esquerda) ordenação dos pontos de amostragem no espaço formado pelos dois primeiros fatores; direita) círculo de correlação dos parâmetros hidro-morfológicos com os dois primeiros fatores.

the evaluation carried out in $2015 / 2017$ and 2020 or between the various sampling points. However, it should be noted that an increasing percentage of smaller diameter materials moved from upstream to downstream (more evident at sites D and E).

The ordination of environmental parameters (sampling sites/dates) along the first two PCA axes
(62\% of the variability) (Fig. 4, Table S2, Supplementary information, available at http:/www. limnetica.net/en/limnetica) shows that the 2015/ 2017 samples were dispersed across the first two axes with apparent differentiation between samples collected at sites A and B from the samples collected at sites C, D and E, as well as the values 
Table 3. Values of environmental parameters. Valores dos parâmetros ambientais.

\begin{tabular}{|c|c|c|c|c|c|c|c|c|c|}
\hline & & AVH & QBR & $\begin{array}{l}\text { Flow } \\
\left(\mathrm{m}^{3} / \mathbf{s}\right)\end{array}$ & $\begin{array}{c}\text { Macrophytes } \\
(\%)\end{array}$ & $\begin{array}{c}\text { Canopy } \\
\text { (\%) }\end{array}$ & pH & $\begin{array}{c}\text { Conductivity } \\
(\mu \mathrm{S} / \mathrm{cm})\end{array}$ & $\begin{array}{c}\mathrm{O}_{2} \text { Saturation } \\
(\%)\end{array}$ \\
\hline \multirow{4}{*}{ A } & Winter $15 / 17$ & 124 & 10 & 0.2755 & 2.5 & 0.0 & 7.21 & 338.00 & 72.80 \\
\hline & Summer 15/17 & 135 & 15 & 0.1542 & 10.0 & 0.0 & 6.98 & 358.50 & 53.20 \\
\hline & Winter 20 & 115 & 20 & 0.2911 & 5.0 & 0.0 & 7.90 & 326.00 & 67.50 \\
\hline & Summer 20 & 119 & 20 & 0.0834 & 50.0 & 0.0 & 7.73 & 338.00 & 77.50 \\
\hline \multirow{4}{*}{ B } & Winter $15 / 17$ & 122 & 30 & 0.4775 & 10.0 & 5.0 & 7.59 & 333.50 & 79.10 \\
\hline & Summer 15/17 & 130 & 25 & 0.1738 & 10.0 & 5.0 & 7.21 & 344.50 & 67.60 \\
\hline & Winter 20 & 96 & 0 & 0.5653 & 0.0 & 0.0 & 8.00 & 347.00 & 70.20 \\
\hline & Summer 20 & 101 & 0 & 0.4459 & 10.0 & 0.0 & 7.61 & 352.00 & 71.60 \\
\hline \multirow{4}{*}{$\mathrm{C}$} & Winter $15 / 17$ & 134 & 35 & 1.0298 & 2.5 & 12.5 & 7.29 & 396.50 & 70.75 \\
\hline & Summer 15/17 & 140 & 35 & 0.7450 & 10.0 & 15.0 & 6.97 & 376.00 & 67.70 \\
\hline & Winter 20 & 111 & 10 & 0.9005 & 2.0 & 20.0 & 8.10 & 348.00 & 68.60 \\
\hline & Summer 20 & 122 & 10 & 0.4896 & 45.0 & 20.0 & 7.56 & 379.00 & 70.10 \\
\hline \multirow{4}{*}{$\mathrm{D}$} & Winter $15 / 17$ & 142 & 50 & 1.5193 & 2.5 & 22.5 & 7.64 & 378.50 & 74.80 \\
\hline & Summer $15 / 17$ & 147 & 45 & 0.2778 & 7.5 & 25.0 & 7.25 & 463.00 & 70.70 \\
\hline & Winter 20 & 118 & 20 & 1.0170 & 5.0 & 15.0 & 7.90 & 370.00 & 73.50 \\
\hline & Summer 20 & 130 & 20 & 0.3320 & 15.0 & 25.0 & 7.42 & 385.00 & 76.50 \\
\hline$E$ & Winter $15 / 17$ & 116 & 55 & 1.6151 & 2.5 & 57.5 & 7.65 & 406.00 & 73.85 \\
\hline
\end{tabular}

- Very good; - - Good; - - Medium; - - Bad; $\square$ - Very bad;

of QBR and AVH (Table 3) at the first two sites.

The environmental conditions in 2020 seem to show greater homogeneity between the sampling sites that present low conductivity (from $330 \mu \mathrm{S} / \mathrm{cm}$ to $640 \mu \mathrm{S} / \mathrm{cm}$ in $2015 / 17$ and from $320 \mu \mathrm{S} / \mathrm{cm}$ to $400 \mu \mathrm{S} / \mathrm{cm}$ in 2020 ), higher oxygen saturation (from $40 \%$ to $75 \%$ in $2015 / 17$ and from $67.5 \%$ to $80 \%$ in 2020) and lower values of QBR and AVH (Table 3).

The hydromorphological quality was higher in 2015/17 than in 2020. In terms of the QBR, which evaluates a quality more related to the riparian vegetation, the values ranged from medium, poor and very poor to poor/very poor, with an increase in the latter classification. In terms of AVH, which analyses the general state of the channel, the values ranged from medium and good quality to a quality between medium and poor. These changes were more evident at the last 3 sampling sites. (Table 3 )

\section{Benthic macroinvertebrate communities}

The analysis of the taxonomic composition of the samples considered (Fig. 5) indicates that the taxa present in 2020 belong to practically the same taxa as in 2015/17 but with a predominance of Ephemeroptera with respect to Diptera and Annelida. Additionally, in 2020, some specimens of Trichoptera appear (Figs. 5 and 8).

The analysis of the PCA (Fig. 6) shows that there is an apparent separation between the samples collected in 2015/17 and 2020, considering the first two factors of the PCA (variability of $69.97 \%$ ). The samples collected in 2015/17 present a higher percentage of Diptera and lower 


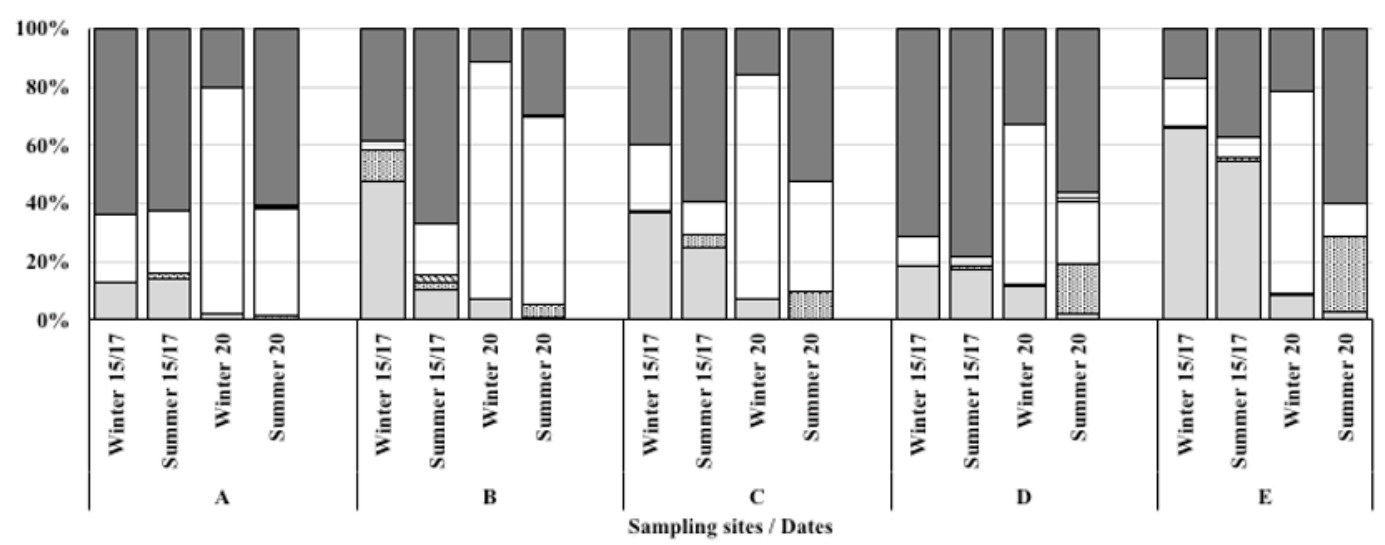

$\square$ Annelida e plathylelminthes $\square$ Mollusca $\$$ Crustacea $\square$ Ephemeroptera mOdonata $\Xi$ Coleoptera $\boxminus$ Trichoptera $\square$ Diptera

Figure 5. Spatial and temporal variation of the taxa composition of the macroinvertebrate communities. Variação espacial e temporal da composição taxonómica das comunidades de macroinvertebrados bentónicos.
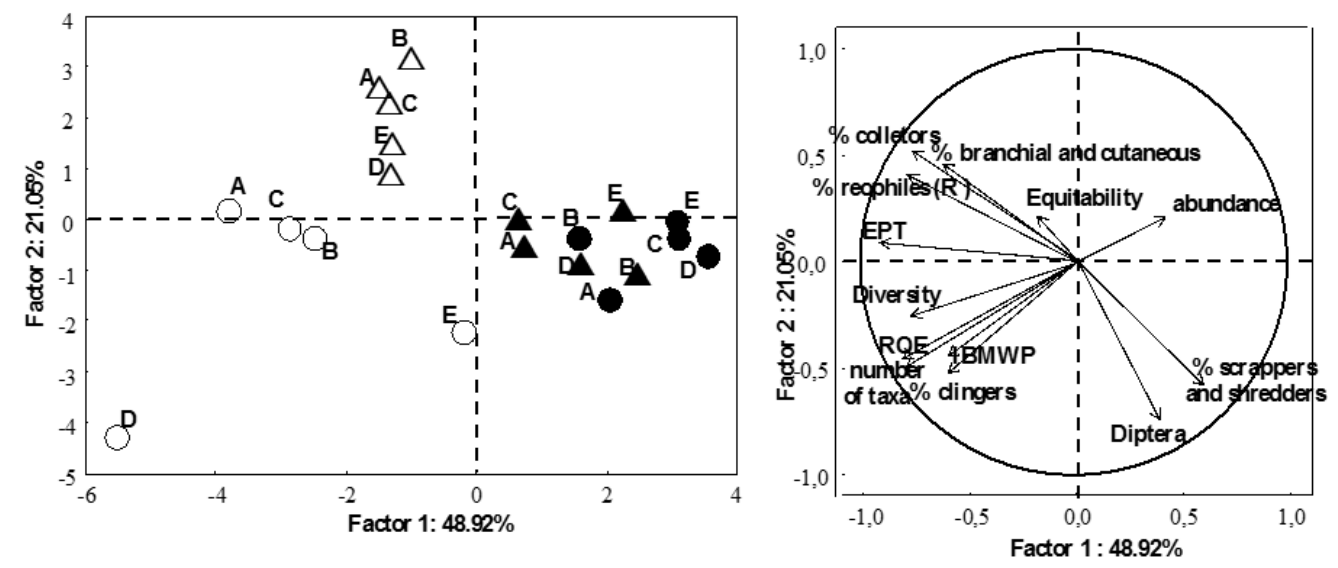

$\boldsymbol{\Delta}$ - Winter 2015/17 $\triangle$ - Winter $2020 \bullet$ - Summer 2015/17 ○ - Summer 2020

Figure 6. Principal components analysis (PCA) based on the mean values of the macroinvertebrate metrics: left) sample ordination of all sampling sites in the space formed by the two first factors; right) correlation circle of metrics with the two first factors. Análise em componentes principais (PCA) baseada nos valores médios das métricas calculadas com base nos dados de macroinvertebrados: esquerda) ordenação dos pontos de amostragem no espaço formado pelos dois primeiros fatores; direita) círculo de correlação das métricas com os dois primeiros fatores.

values of EPT and diversity, as well as a greater number of organisms (Fig. 6 and Table S2). In contrast, the samples collected in 2020 have a greater positive correlation with the diversity and number of rates, as well as the values of water quality indices, and are dominated by organisms with gills and/or skin respiration, collectors and rheophiles (Table S2).

The analysis of the results obtained with the two biological water quality indices shows that there was an improvement tendency in the biological quality (Table 4).

In terms of IBMWP, the values ranged from poor (3 values) and very poor ( 7 values) to me- 
Table 4. Values of the biological water quality indexes. Valores para os índices de qualidade biológica da água.

\begin{tabular}{lll|c|c|c|c}
\hline & & Site A & Site B & Site C & Site D & Site E \\
\hline \multirow{3}{*}{ IBMWP } & Winter15/17 & 15 & 14 & 16 & 14 & 17 \\
\cline { 2 - 8 } & Summer15/17 & 20 & 15 & 13 & 12 & 12 \\
\cline { 2 - 7 } & Winter 20 & 16 & 11 & 16 & 19 & 19 \\
\cline { 2 - 7 } & Summer 20 & 30 & 34 & 24 & 46 & 23 \\
\hline \multirow{4}{*}{ EQN } & Winter 15/17 & 0.23 & 0.20 & 0.24 & 0.22 & 0.22 \\
\cline { 2 - 7 } & Summer 15/17 & 0.25 & 0.22 & 0.17 & 0.17 & 0.24 \\
\cline { 2 - 7 } & Winter 20 & 0.23 & 0.21 & 0.24 & 0.25 & 0.25 \\
\cline { 2 - 8 } & Summer 20 & 0.28 & 0.29 & 0.27 & 0.38 & 0.27 \\
\hline
\end{tabular}

dium ( 1 value), poor ( 8 values and very poor (1 value). In terms of EQN, the values ranged from poor (4 values) and very poor (6 values) to poor ( 9 values) and very poor ( 1 value).

The analysis of the composition of the benthic macroinvertebrate communities taking into account the taxonomic classification of the organisms, their biological traits, ecology and sensitivity to pollution (according to the classification made by IBMWP) carried out through the distribution in space of the various samples gen-
A)

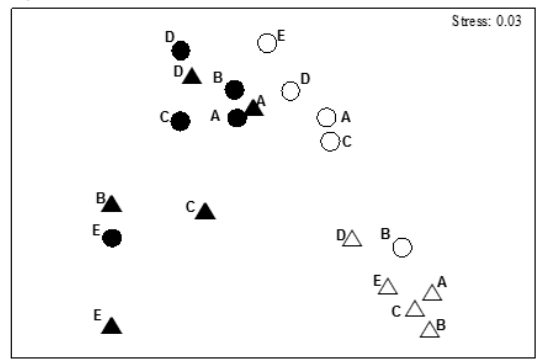

ANOSIM test: $\mathrm{R}_{\text {global }}=0.542$

C)

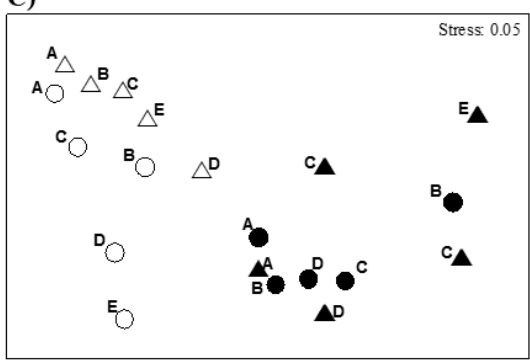

ANOSIM test: $\mathrm{R}_{\text {global }}=0.816$

E)

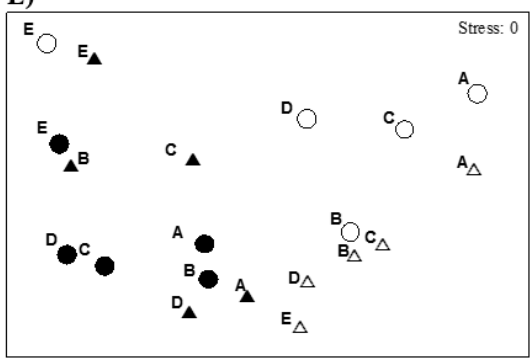

ANOSIM test: Rglobal $=0.515$
B)

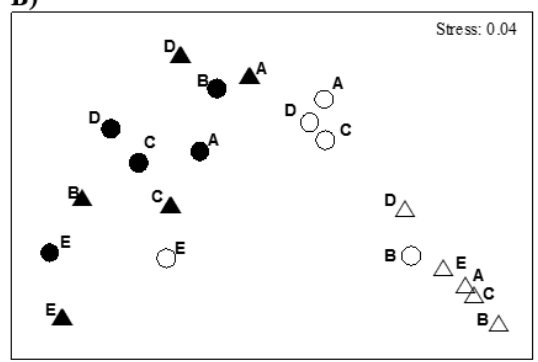

ANOSIM test: Rglobal $=0.617$

D)

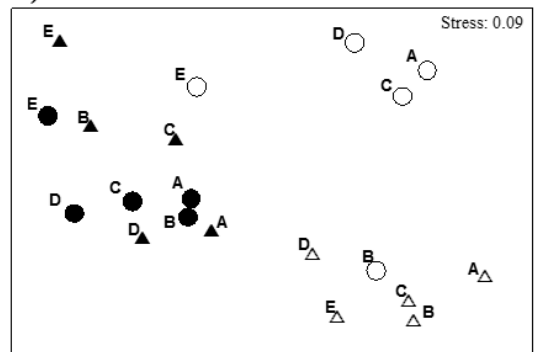

ANOSIM test: Rglobal $=0.66$

F)

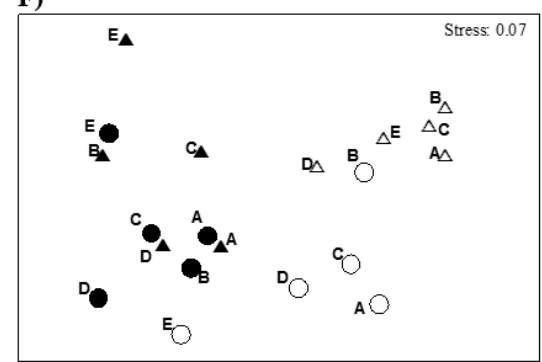

ANOSIM test: Rglobal $=0.647$

$\Delta$ - Winter 2015/17 $\triangle$ - Winter 2020

- Summer 2015/17 ○ - Summer 2020

Figure 7. Sample ordination made by the n-MDS technique with Euclidean distances between samples using taxa (A) and functional groups (B - breathing groups; C - feeding groups; D habitat/locomotion preferences; E - flow preferences; F - IBMWP scores) and average abundance (by SIMPER analysis) of each taxa in each group of samples (b). Ordenação das amostras através da análise n-MDS usando as distâncias euclideanas entre os taxa (a) e abundância média (através da análise SIMPER) de cada taxa em cada grupo de amostras (b). 


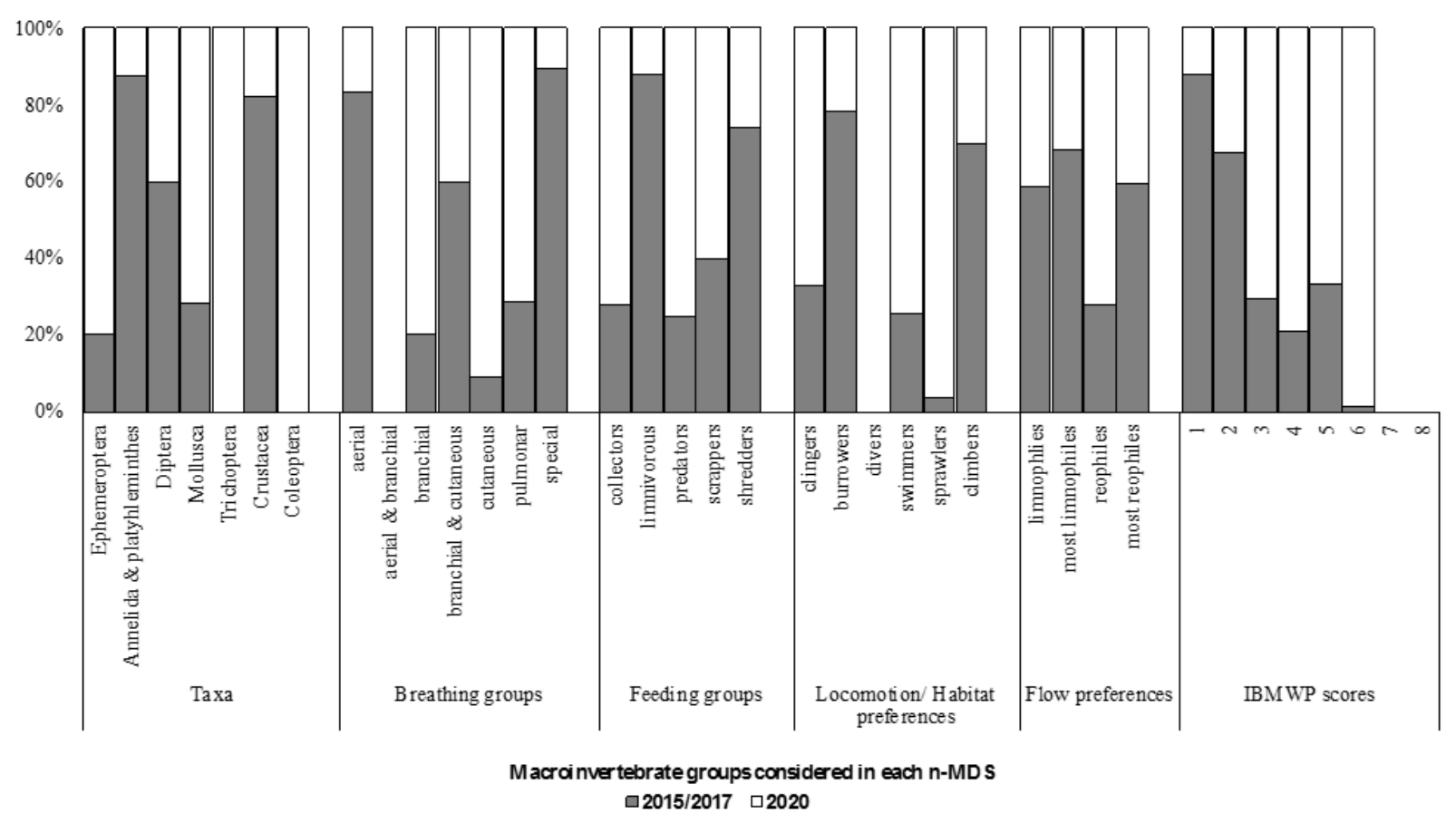

Figure 8. Average abundance (by SIMPER analysis) of each taxa and functional group in group of samples (2015/17 and 2020). Abundância média (através da análise SIMPER) de cada taxa e grupo funcional em cada grupo de amostras (2015/17 e 2020).

erated by the analysis of n-MDS (Fig. 7), shows that, in most of the situations analysed, there is a good separation between the samples analysed in the two groups considered a priori $(2015 / 17$ and 2020). The difference between the two groups was more significant when looking at the composition of the various samples collected considering the method of feeding for the organisms (ANOSIM test Rglobal $=0.816$ ). In the distribution of the samples considering aspects such as the respiratory physiology of the organisms, their type of locomotion and their sensitivity to pollution, the separation of the two groups considered is not as significant (ANOSIM test Rglobal approximately $0.6)$ due to the greater proximity of the samples collected at sampling point E in June 2020 with samples collected in the $2015 / 17$ period.

In the analysis of the taxonomic composition of the samples (ANOSIM test Rglobal of 0.542 and 0.515 , respectively) and taking into account the preference of the organisms for different flow regimes, this separation is even less evident.
The results of the SIMPER analysis show a separation of the 2 groups of samples (Fig. 8): i) Samples collected in 2015/17 have a greater number of organisms belonging to Diptera, Annelida, and Platyhelminthes, organisms with gills and skin respiration and some special types of respiration, and shredders, limnivores and collectors, which live buried in the substrate, or climbers with greater adaptive plasticity to different flow regimes and with less sensitivity to organic pollution; ii) Samples collected in 2020 have a predominance of Ephemeroptera and Diptera, organisms with branchial or branchia and cutaneous respiration, collectors, swimmers, rheophiles and organisms with greater sensitivity to pollution.

\section{DISCUSSION}

One year after the conclusion of the first phase of the rehabilitation works (Jesus et al., 2020), it was possible to detect some differences in the river, not only from simple observations but also 
in terms of some of the parameters related to its ecological status.

\section{Effect of river rehabilitation on environmental parameters}

Even though the area surrounding the river seemed visually much cleaner and more beautiful, the analysis of the riparian corridor and habitat quality had worsened, especially at points $\mathrm{D}$ and $\mathrm{E}$, which is evident from the analysis of the two hydromorphological quality indices calculated and the hydromorphological parameters (Tables 3 and 4). This may be due to the nature of the interventions as well as the short time that elapsed from the conclusion of the work to the date of this study.

The work carried out on the last 4 kilometres (sampling sites D and E) of the river included the digging of ditches on the riverbanks for the installation of an outfall, which led to the removal of most of the pre-existing vegetation. To overcome this disturbance, rigid structures (stone walls) and/or seminatural structures were installed (green braid), and new vegetation was planted to stabilize the banks. This vegetation is currently in the growth and rooting phase.

Contrary to what happened with the parameters related to the quality of the habitat, it appears that an improvement in the physical-chemical quality of the water throughout the entire watercourse had occurred, which is evidenced by the reduction in the conductivity values and by the increased saturation of dissolved oxygen (Table 3 and Fig. 4) related to a probable reduction in the concentration of organic matter (Gücker et al., 2006, Ladrera \& Prat, 2013). These may be linked not only to the elimination of effluent discharges from the WWTPs that reduced organic and nutrient loads on the local scale but also to some interventions that were carried out on the riverbed (as indicated by Mrozińska et al., 2018) as cut-off channels (bypass), semipalisades, and single groynes that enhanced nutrient retention and transformation processes through temporary storage, assimilation, adsorption, or permanent removal through coupled nitrification and denitrification and by the oxygenation of water. Similar measures have been described by Newcomer
Johnson et al. (2016).

For a better evaluation of the impact of river rehabilitation on the physical-chemical qualities of the water, it would be important to carry out an evaluation of more parameters, such as the concentration of nutrients (nitrates, nitrites, ammonium and phosphates) and the amount of DOM, as well as an extended evaluation over time (as was recommended by Weber, 2017). This was not done since the main objective of the work was to evaluate mainly the effects of the rehabilitation of the river on the benthic macroinvertebrate communities.

\section{Effect of river rehabilitation on benthic mac- roinvertebrate communities}

The benthic macroinvertebrate communities present in the Tinto River before the rehabilitation process were typical river communities subject to a high degree of environmental degradation. The communities had a great abundance of organisms and low taxonomic richness, which explains the relatively low values of diversity and equitability. They were dominated by the presence of Annelida and Diptera, organisms that have very low sensitivity to pollution overall (Jesus et al., 2020).

One year after the rehabilitation of the river, the results show that there was a change in the taxonomic composition of the communities that were now dominated by Ephemeroptera and Diptera (Fig. 5). As expected, there was a reduction in the abundance of organisms but an increase in taxonomic richness, which had an effect on their taxonomic diversity (Fig. 4C), which was higher than that in the samples collected in 2015/17 (Miller et al., 2010, Kail et al., 2012).

These changes are also reflected in the functional structure of the communities, which became dominated by organisms that are more sensitive to pollution as they depend more on the concentration of oxygen dissolved in the water (with branchial breathing or branchial and cutaneous breathing, e.g., the Diptera of the Chironomidae family). In samples collected in 2020, there was a lower proportion of sprawlers, probably due to the reduction in benthic food available and an increase in active swimmers (Merritt et al., 2002), 
collectors and organisms with a preference for rheophile conditions (Figs. 7 and 8). According to Merritt et al. (2002), the increased proportion of scrapers and filtering collectors in the 2020 samples may suggest a higher stability of the habitat, which seems to be contradictory to the results obtained with the AVH but can be explained by the decrease in the proportion of shredders (potentially reflecting the CPOM/FPOM ratio).

The analysis of the results indicates that there were still some external factors that keep the ecological status of the river at a poor level. This may explain some similarities of the results obtained at sampling site $\mathrm{E}$ in the summer of 2020 with those of previous campaigns (Figs. 7 and 8).

This situation could be because this is a point very close to the mouth of the river where there is a cumulative effect of some instances of periodic organic pollution phenomena that occur and persist in the summer months, which becomes more evident when the water flow river is lower (Table 3).

Despite this fact, all changes in the macroinvertebrate communities seem to indicate that the biological quality of the water had improved slightly (Table 4).

One year seems insufficient for a complete change in the composition of the macroinvertebrate communities, as other authors have recently described (Al-Zankana et al., 2020). The assumption underlying most rehabilitation projects (Lepori et al., 2006, Miller et al., 2010, Roni et al., 2006) that physical rehabilitation (which generally means an increase in habitat heterogeneity) leads to increases in biodiversity and population density can somehow explain the results obtained. This assumption is sometimes called the "field of dreams" hypothesis (i.e., if you build it, they will come), which has been the core paradigm in most projects. This idea is founded on the observed positive relationship between greater (natural) riverbed physical diversity and taxon richness. In-stream mechanisms thought to underpin this relationship include increased space, food, and refugia (Palmer et al., 2010).

Despite the aforementioned results, this study shows that there was a positive evolution, mainly with the benthic communities, which can be explained by the small size of the watercourse and the fact that the two areas of intervention made up more than half of the river, contrary to what happens in most projects which generally have small areas of intervention in comparison to the total catchment size, often not exceeding a few kilometres of the river length. If not removed or mitigated, environmental stressors acting at larger spatial scales, such as water quality stressors, and catchment land use and flow alterations, often have an overriding influence on the recovery processes in these small, restored sections (Feld et al., 2011, Verdonschot et al., 2013; Wahl et al., 2013).

Although in most rehabilitation projects, the diversity of habitats, including microhabitats, increases considerably, this does not automatically result in a strong positive response in macroinvertebrate assemblages (Jähnig \& Lorenz, 2008, Louhi et al., 2011). In this study, the opposite appeared to happen because the quality of the habitat seemed to have worsened and there was an improvement in the communities of benthic macroinvestments. This can be partially explained by the fact that the problems this river presented were mostly caused by the discharges of the wastewater treatment plants that contributed to the higher concentration of organic matter in the water (Jesus et al., 2020).

\section{Relationship between environmental parame- ters and the biota}

The relationship between an ecological metric and environmental variables may inform the source of stress or response experienced by an ecological indicator (Allan, 2004). These relationships seem to be demonstrated between benthic macroinvertebrate communities and physicochemical variables in this work, as in many other studies (Dudgeon, 2012, Kim et al.,2017), making us believe that the reduction in water pollution (reduction of the organic matter and nutrient concentration reflected, in part, by the conductivity values and the increase in the oxygen saturation) at the catchment scale are possible causes for the apparent rehabilitation success.

While land use and the quality of riparian vegetation do not seem to be in line with the biotic metrics (e.g., family richness or abundance 
of Ephemeroptera, Plecoptera, and Trichoptera, see Figs. 4 and 7), instream factors may be simultaneously related to other metrics (e.g., benthic invertebrate feeding types, Theodoropoulos et al. (2015).

Understanding the relationship between environmental parameters and biotic communities is one of the major problems for this kind of ecological study (Tockner et al., 2010) because it is difficult to predict the effects of multiple stressors derived from different land-use patterns at various spatial scales on benthic invertebrate assemblages.

This study demonstrated the significant potential of urban, artificial rehabilitation measures to improve the diversity of aquatic invertebrates, including species of high conservation value (Figs. 6, 7 and Table 4) (Weber et al., 2017).

\section{CONCLUSIONS}

After comparing the data, it is possible to conclude that in general, there is an improvement in the Tinto River ecological status despite the short time that has elapsed since the implementation of rehabilitation measures. There is homogenisation of habitat quality - only the last few km's (points C, D and E) show a decrease in habitat quality, which may be explained by the short time elapsed since the interventions around the river for the WWTP's outfall construction. There is an apparent improvement in the physical-chemical quality with a decrease in conductivity values at points $\mathrm{C}, \mathrm{D}$ and $\mathrm{E}$ and an increase in the percentage of oxygen saturation in the water.

These results indicate that there has been a transformation in the benthic communities, with an increase in groups of organisms with sensitivity to pollution, such as organisms with branchial breathing, and an increase in organisms with a preference for more oxygenated and running water, and a decrease in the percentage of Diptera and Annelida, all showing a reduction in the environmental stress of the river due to water pollution.

In addition, there are some features that indicate an improvement in the ecological quality, such as a decrease in water turbidity and the amount of organic matter in the substrates, as well as the first observations of the presence of some fish since 2013.

\section{ACKNOWLEDGMENTS}

Research work funded by LIPOR, FFP and FCT - Fundação para a Ciência e Tecnologia in the scope of FCT Project UID/Multi/04546/2013.

\section{REFERENCES}

Al-Zankana A. F. A., Matheson, T. \& Harper, D. M. (2020). How strong is the evidence-based on macroinvertebrate community responses that river restoration works? Ecohydrology \& Hydrobiology, 20, 196-214. DOI: 10.1016/j. ecohyd.2019.11.001

Alba-Tercedor, J., Jáimez-Cuéllar, P., Álvarez, M., Avilés, J., Bonada, N., Casas, J., ... ZamoraMuñoz, C. (2002). Caracterización del estado ecológico de ríos mediterráneos ibéricos mediante el índice IBMWP (antes BMWP'). Limnetica, 21 (3-4), 175-185.

Allan J. D. (2004). Landscapes and riverscapes: the influence of land use on stream ecosystems. Annual Review of Ecology, 35, 257-284.

Barbour, M. T. (1997). The re-invention of biological assessment in the U. S. Human and Ecological Risk Assessment, 3(6), 933-940.

Carter, J. L., Resh, V. H., \& Hannaford, M. J. (2017). Macroinvertebrates as biotic indicators of environmental quality. In: Methods in Stream Ecology, third ed. pp. 293-318. DOI: 10.1016/B978-0-12-813047-6.00016-4

Casatti, L., Langeani, F., Silva, A. M. \& Castro, R. M, C. (2006). Stream fish, water and habitat quality in a pasture dominated basin, Southeastern Brazil. Brazilian Journal of Biology, 66(2B), 681-696.

Clarcke K. R. \& Warwick, R. M. (1994). Change in marine communities: an approach to statistical analysis and interpretation. Plymouth Marine Laboratory, UK.

Concepción E. D., Moretti, M., Altermatt, F., Nobis, M. P. \& Obrist, M. K. (2015). Impacts of urbanisation on biodiversity: The role of species mobility, degree of specialisation and spatial scale. Oikos, 000, 001-012. DOI: 10.1111/ oik.02166

Danehy, R. J., Bilbyr, R. E., Langshaw, B., Evans, D. M., Turner, T. R., Floyd, W. C., ... Duke, S. D. (2012). Biological and water quality re- 
sponses to hydrologic disturbances in thirdorder forested streams. Ecohydrology, 5, 90-98.

Dudgeon, D. (2012). Responses of benthic macroinvertebrate communities to altitude and geology in tributaries of the Sepik River (Papua New Guinea): the influence of taxonomic resolution on the detection of environmental gradients. Freshwater Biology, 57, 1794-1812.

EPA, (1999). Rapid bioassessment protocols dos use in streams and wadeable rivers: periphyton, benthic macroinvertebrates and fish. 2nd ed., United States.

Feld, C. K., Birk, S., Bradley, D. C., Hering, D., Kail, J., Marzin, A., ... Friberg, N. (2011). From natural to degraded rivers and back again: a test of restoration ecology theory and practice. Advances in Ecological Research, 44, 199-209.

Feld, C. K., De Bello, F. \& Dolédec, S. (2014). Biodiversity of traits and species both show weak responses to hydromorphological alteration in lowland river macroinvertebrates. Freshwater Biology, 59, 233-248. DOI: 10.1111/fwb.12260

Grimm, N. B., Grove, J. M., Pickett, S. T. A. \& Redman C. L. (2000). Integrated Approaches to Long-Term Studies of Urban Ecological Systems. Bioscience, 50, 571-584.

Gücker, B., Brauns, M. \& Pusch, M. T. (2006). Effects of wastewater treatment plant discharge on ecosystem structure and function of lowland streams. Journal of the North American Benthological Society, 25 (2), 313-329.

INAG, I. P. (2008a). Manual para a avaliação biológica da qualidade biológica da qualidade da água em sistemas fluviais segundo a Directiva Quadro da Água. Protocolo de amostragem e análise para os macroinvertebrados bentónicos. MAOTDR.

INAG, I. P. (2008b). Tipologia de rios em Portugal Continental no âmbito da implementação da Directiva Quadro da Água. I - Caracterização abiótica. MAOTDR.

INAG, I. P. (2009). Critérios para a classificação do estado das massas de água superficiais. Rios e albufeiras. MAOTDR

Jähnig, S. C. \& Lorenz, A. W. (2008). Substrate-specific macroinvertebrate diversity patterns following stream restoration. Aquatic Sciences, 70, 292-303.
Jesus, T. (2002). Centrais hidroelétricas de pequena dimensão: impacto na dinâmica da comunidade de macroinvertebrados bentónicos e na variação da qualidade da água (Mini-hídrica de Vila Viçosa e "Cascata" do Alva). Dissertação de doutoramento apresentada á Faculdade de Ciências da Universidade do Porto, $235 \mathrm{pp}$.

Jesus, T. (2008). Ecological, anatomical and physiological traits of benthic macroinvertebrates: Their use on the health characterization of freshwater ecosystems. Limnetica, 27 (1), 79-92.

Jesus T., Monteiro, A., Abreu, I. \& Guerreiro, M. J. (2020). Study of the effect of two wastewater treatment plants (WWTP's) discharges on the benthic macroinvertebrate communitie's structure of the River Tinto (Portugal). Limnetica, 39(1), 353-372.

Kail, J., Arle, J. \& Jaehnig, S. C. (2012). Limiting factors and thresholds for macroinvertebrate assemblages in European rivers: empirical evidence from three datasets on water quality, catchment urbanization, and river restoration. Ecological Indicators, 28, 63-72.

Kim J. Y., Kim, P. J., Hwang, S. J., Lee, J. K., Lee, S. W., Park, C. H., ... D. S. Kong, D. S. (2017). Korean stream types based on benthic macroinvertebrate communities according to stream size and altitude. Journal of Freshwater Ecology, 32(1), 741-759.

Ladrera R. \& Prat, N. (2013). Changes in macroinvertebrate community abd biotic indices associated with streamflow regulation and wastewater inputs in Sierra Cebollera Natural Park (La Rioja, Northern Spain). Limnetica, 32(2), 353-372.

Lepori F., Gaul, D., Palm, D. \& Malmqvist, B. (2006). Food-web responses to restoration of channel heterogeneity in boreal streams. $\mathrm{Ca}$ nadian Journal of Fisheries Aquatic Sciences, 63 (11), 2478-2486.

Louhi P., Mykrä, H., Paavola, R., Huusko, A., Vehanen, T., Mäki-Petäys, A. \& Muotka. T. (2011). Twenty years of stream restoration in Finland: little response by benthic macroinvertebrate communities. Ecological Applications, 21, 1950-1961.

Merritt R. W., Cummins, K. W., Berg, M. B., 
Novak, J. A., Higgins, M. J., Wessel, K. J. \& Lessard, J. (2002) Development and application of a macroinvertebrate functional-group approach in the bioassessment of remnant river oxbows in southwest Florida. Journal of the North American Benthological Society, 21, 290-310.

Miller, S. W., Budy, P. \& Schmidt, J. C. (2010). Quantifying macroinvertebrate responses to instream habitat restoration: applications of meta-analysis to river restoration. Restoration Ecology, 18, 8-19. DOI: 10.1111/j.1526100X.2009.00605.X

Mrozińska N., Glińska-Lewczuk, K., Burandt, P., Kobus, S., Gotkiewicz, W., Szymańska, M., ... Obolewski K. (2018). Water Quality as an Indicator of Stream Restoration Effects - A Case Study of the Kwacza River Restoration Project. Water, 2018, 10, 1249. DOI: 10.3390/ w10091249

Munné A., Solá, C. \& Prat, N. (1998). QBR: Un índice rápido para la evaluación de la calidad de los ecossistemas de ribera. Tecnologia del Agua: artículos técnicos, 175, 20-37.

Newcomer Johnson, T. A., Kaushal, S. S., Mayer, P. M., Smith, R. M. \& Sivirichi, G. M. (2016). Nutrient Retention in Restored Streams and Rivers: A Global Review and Synthesis. Water, 2016, 8, 116.

Ormerod S. J. (2004). A golden age of river restoration science? Aquatic Conservation, 14(6), 543-549.

Palmer M. A., Menninger, H. L: \& Bernhardt, E. (2010). River restoration, habitat heterogeneity and biodiversity: a failure of theory or practice? Freshwater Biology, 55, 205-222.

Parrinello, G. (2014). Urban Rivers: Remaking Rivers, Cities, and Space in Europe and North America. The AAG Review of Books, 2 (3), 94-96.

Peterson, S. D., (2015). Using Macroinvertebrate Recolonization to Predict Community Recovery: Implications for the Restoration of Kimball Creek (Doctoral dissertation). Murray State University.

Pinho, P., Santos, S., Dias, R., Ferreira, M., Silva, C., Torres, M., Moura E Sá, F. \& Fernandes, R. (2009). Atlas da Grande Área metropolitana do Porto. FEUP. Junta Metropolitana do Porto.
Platts W. S., Megahan, W. F. \& Minshall, G. W. (1983). Methods for evaluating stream, riparian and biotic conditions. USDA.

Quinn, J. M. \& Hickey, C. W. (1990). The Magnitude of the Effects of Substrate Particle Size, Recent Flooding, and Catchment Development on Benthic Invertebrates in 88 New Zealand Rivers. New Zealand. Journal of Marine and Freshwater Research, 24, 411-427.

Resh, V. H. \& Rosenberg, D. M. (1993). Freshwater Biomonitoring and Benthic Macroinvertebrates. Springer US, Chapman and Hall, New York, pp. 488 ISBN 041202251 6. DOI: 10.1002/aqc. 3270040110

Roni, P. \& Beechie, T. (2013). Stream and Watershed Restoration: A Guide to Restoring Riverine Processes and Habitats. Wiley-Blackwell.

Roni P., Bennett, T., Morley, S., Pess, G. R., Hanson, K., Slyke, D. V. \& Olm- Stead, P. (2006). Rehabilitation of bedrock stream channels: the effects of boulder weir placement on aquatic habitat and biota. River Research and Applications, 22 (9), 967-980.

Roni, P. \& Quimby, E. (2005). Monitoring Stream and Watershed Restoration. CABI .

Rubin, Z., Kondolf, G. M. \& Rios-Touma, B. (2017). Evaluating stream restoration projects: what do we learn from monitoring? Water, 9 (3), 174. DOI: 10.3390/w9030174

Sheehan, M. O. 2001. City Limits: Putting the Brakes on Sprawl. Worldwatch Paper No. 156, Worldwatch Institute, Washington DC.

Theodoropoulos C., Aspridis, D. \& IliopoulouGeorgudaki, J.. (2015). The influence of land use on freshwater macroinvertebrates in a regulated and temporary Mediterranean river network. Hydrobiologia, 751, 201-213. DOI: 10.1007/s10750-015-2187-3

Tockner, K., M. Pusch, D. Borchardt \& M. S. Lorang. 2010. Multiple stressors in coupled river-floodplain ecosystems. Freshwater Biology, 55, 135-151.

Vieira, N. M. (2009). Qualidade Química e bacteriológica das Águas das ribeiras do Porto. Dissertação de mestrado apresentada à Universidade de Aveiro, Universidade de Aveiro

Verdonschot, P. F. M., Spears, B. M., Feld, C. K., Brucet, S., Keizer-Vlek, H., Borja, A., ... Johnson, R. K. (2013). A comparative review 
of recovery processes in rivers, lakes, estuarine and coastal waters. Hydrobiologia, 704, 453-474.

Wahl, C. M., Neils, A. \& Hooper, D. (2013). Impacts of land use at the catchment scale constrain the habitat benefits of stream riparian buffers. Freshwater Biology, 58, 2310-2324.

Weber A., Garcia, X. F. \& C. Wolter, C. (2017). Habitat rehabilitation in urban waterways: the ecological potential of bank protection structures for benthic invertebrates. Urban Ecosystem (2017), 20, 759-773. DOI: 10.1007/ s11252-017-0647-4
Yoder, C. O. \& Rankin, E. T. (1995). Biological Response Signatures and the Area of Degradation Value: New Tools for Interpreting Multimetric Data. In: Davis, W.S. and Simon, T.P., Eds., Biological Assessment and Criteria - Tools for Water Resource Planning and Decision Making, Lewis Publ., Boca Raton, 263-286.

Zhang, Y., Liu, L., Cheng, L., Cai, Y., Yin, H., Gao, J. \& Gao, Y. (2014). Macroinvertebrate assemblages in streams and rivers of a highly developed region (Lake Taihu Basin, China). Aquatic Biology, 23, 15-28. 